\title{
Penerapan Fungsi Manajemen Pada Kebijakan Kawasan Tanpa Rokok Di Kota Cirebon
}

\author{
Cucu Herawati ${ }^{1 *}$, Iin Kristanti ${ }^{2}$, Siti Rodatul Jannah ${ }^{3}$ \\ Sekolah Tinggi Ilmu Kesehatan Cirebon \\ ${ }^{1}$ e-mail: cucueherawatie @ gmail.com \\ ${ }^{2}$ e-mail: inkris76@gmail.com \\ 3 e-mail: dodotuljannah@gmail.com \\ *Corresponding Author
}

\begin{abstract}
ABSTRAK
Tujuan penelitian ini untuk mengetahui penerapan fungsi manajemen pada kebijakan Kawasan Tanpa Rokok (KTR) Di Kota Cirebon. Rancangan penelitian ini menggunakan jenis penelitian kualitatif. Subjek penelitian yaitu petugas KTR dan masyarakat dengan teknik purposive sampling. Pengukuran validitas data menggunakan metode triangulasi yaitu triangulasi sumber, triangulasi data dan triangulasi metoda. Analisis data berupa situasi sosial yang terdiri atas Place, Actor an Activity (PAA), selanjutnya melakukan observasi, wawancara mendalam (indepth interview) dan telaah dokumen. Hasil penelitian menunjukkan bahwa fungsi manajemen kebijakan KTR masih belum sepenuhnya berhasil, sosialisasi telah dilakukan sejak adanya aturan KTR, petugas KTR sudah memasang tanda larangan merokok tapi belum ada tempat khusus untuk merokok. Kesiapan pelaksanaan belum sepenuhnya menunjukkan sikap mendukung terhadap kebijakan KTR, namum dalam pelaksanaanya masih banyak masyarakat dan petugas yang melanggar. Perlu dilakukan razia rutin terhadap lingkungan KTR dan ditingkatkan kembali proses pengawasan, pembinaan, komunikasi tentang pentingnya menerapkan kebijakan KTR.
\end{abstract}

Kata kunci: Fungsi Manajemen; Kebijakan; Kawasan Tanpa Rokok

\begin{abstract}
The purpose of this study is to determine the application of management functions to the policy of No Smoking Areas (NSA) in Cirebon City. This research design uses qualitative research. The research subjects were NSA officers and the community using the purposive sampling technique. Measuring the validity of the data using the triangulation method, namely triangulation of sources, triangulation of data, and triangulation of methods. Data analysis in the form of social situations consisting of place, actor, and activity (PAA), then making observations, in-depth interviews (in-depth interview), and document review. The results show that the management function of the NSA policy is still not fully successful, socialization has been carried out since the existence of the NSA regulation, NSA officers have posted a smoking ban sign but there is no special place for smoking Implementation readiness has not fully demonstrated a supportive attitude towards the NSA policy, however, in its implementation, there are still many people and officers who violate it. It is necessary to carry out routine raids on the NSA environment and to improve the process of supervision, guidance, communication about the importance of implementing the NSA policy.
\end{abstract}

Keywords: Management Function; Policy; No Smoking Area 


\section{PENDAHULUAN}

Tingkat kesehatan yang baik pada suatu Kota akan berpengaruh pada tingkat kesehatan nasional. Semakin baik tingkat kesehatan penduduk pada suatu Kota maka semakin baik pula tingkat kesehatan pada suatu negara. Pada masa kini, banyak orang yang tidak peduli dengan kesehatan sendiri, pola hidup masyarakat yang kurang baik salah satunya adalah merokok.(Huri, Hernawan, \& Seran, 2019) Rokok menjadi pengawasan di Indonesia, karena menyebabkan 5,4 juta kematian pada tahun 2006, jumlah masyarakat Indonesia yang merokok setiap hari adalah 658 juta orang, jika dikalikan dengan rata-rata jumlah rokok yang dikonsumsi sebanyak 240 milyar batang perhari, akan setara dengan Rp 330 milyar perhari. Tingginya angka konsumsi rokok di Indonesia dipengaruhi oleh cukai rokok Indonesia yang sangat rendah yaitu sebesar 27\% dari harga jual, cukai Indonesia merupakan cukai terendah ke dua di negara Asean (Badan Penelitian dan Pengembangan Kesehatan Kementrian RI, 2018). Pada tahun 2010, usia rata-rata seorang mulai merokok secara nasional adalah usia 17,6 tahun, usia paling dini memulai merokok dari usia 5-9 tahun. Prevalensi merokok berdasarkan usianya, usia mulai merokok pada usia 5-9 tahun sebanyak 1,7\%, usia 10-14 tahun sebesar 17,5\%, usia 15-19 tahun 43,5\%, usia 2024 tahun sebesar 14,6\%. Data tersebut menunjukkan betapa memprihatinkan perilaku merokok di Indonesia (Maharrani, Isniati, \& Kasni Astiena, 2015).

Pemerintah melakukan upaya penurunan angka penyakit tidak menular yang disebabkan oleh kebiasaan merokok dengan mengeluarkan Undang-Undang Tentang Kesehatan Nomor 36 Tahun 2009, yang menyebutkan bahwa produk tembakau merupakan zat adiktif yang peredaran dan konsumsinya harus dikendalikan. Dalam pasal 115 ayat (2) dan pasal 52 Peraturan Pemerintah Nomor 109 Tahun 2012 tentang pengamanan bahan yang mengandung zat adiktif berupa produk tembakau, Pemerintah daerah wajib menetapkan Kawasan Tanpa Rokok (KTR). Sejak tahun 1999, melalui PP 19/2003 tentang pengamanan rokok bagi kesehatan, Indonesia telah memiliki peraturan untuk melarang orang merokok di tempat-tempat yang telah di tetapkan. Namun peraturan tersebut belum menerapkan 100\% kawasan bebas asap rokok karena masih dibolehkan membuat ruang khusus untuk merokok atau smoking area dengan ventilasi udara pada fasilitas umum dan tempat kerja. Dengan adanya ruang untuk merokok, kebijakan KTR nyaris tanpa resistensi. Pada kenyataannya ruang merokok atau smoking area dengan ventilasi udara tersebut secara ilmiah terbukti tidak efektif untuk melindungi perokok pasif, efek karsinogen yang ditimbulkan dari orang yang merokok di ruangan yang sama karena teknologi ventilasi yang paling modern sekalipun tidak dapat menghilangkan racun berbahaya yang terkandung dalam asap rokok (Ariska, 2017). 
Masalah rokok merupakan masalah nasional dan diprioritaskan upaya penanggulangannya karena menyangkut berbagai aspek permasalahan dalam kehidupan, yaitu aspek ekonomi, sosial politik dan terutama aspek kesehatan. Semua orang berhak dilindungi kesehatannya dari paparan asap rokok orang lain. Karena itu, salah satu upaya efektif untuk melindungi seluruh masyarakat dari asap rokok orang lain adalah melalui penerapan KTR. Penerapan KTR memungkinkan masyarakat untuk dapat menikmati udara bersih dan sehat (Ehan, 2015). Perlunya KTR merupakan arahan kepada pemerintah daerah untuk mengeluarkan kebijakan pelarangan merokok di tempat-tempat yang sudah ditentukan, namun masih sedikit pemerintah daerah yang menerapkan kawasan tanpa rokok. Pada tanggal 25 September 2015 telah ditetapkannya PERDA Kota Cirebon Nomor 8 Tahun 2015 tentang KTR. Dalam PERDA tentang KTR tersebut, terdapat tempat-tempat yang telah ditetapkan yaitu: fasilitas pelayanan kesehatan, tempat proses belajar mengajar, tempat anak bermain, tempat ibadah, angkutan umum dan kendaraan dinas pemerintah, tempat kerja, tempat umum (Saifullah, Ikbal, \& Thamrin, 2019). Namun dalam perencanaan terkait dengan sosialisasi pasca peluncuran atau penyebarluasan informasi tentang KTR masih belum menyeluruh di pahami oleh semua pihak terutama oleh masyarakat, sehingga masih banyak sekali terlihat perilaku tokoh masyarakat dan masyarakat di Kota Cirebon tidak menunjukkan adanya kepatuhan terhadap peraturan tersebut.

Kota Cirebon merupakan salah satu kota yang telah menerapkan KTR wujud penerapan kebijakan dibuatnya informasi dalam bentuk tanda larangan di beberapa area yang di larang untuk merokok. Namun masih banyak orang yang merokok di area tersebut. Ini menunjukkan masih belum semuanya memahami adanya KTR, kenyataan yang memperkuat hal tersebut masih terlihatnya perokok yang merokok di area KTR terutama di instansi pemerintah dan angkutan umum. Berdasarkan hasil yustisi/razia pada Tahun 2018 terdapat 50\% pelanggar dari 60\% sasaran, pada Tahun 2019 terdapat 45\% pelanggar dari 60\% sasaran dan pada bulan Maret Tahun 2020 terdapat 35\% pelanggar dari 60\% sasaran yustisi (Wali Kota Cirebon, 2015). Hal ini perlu menjadi perhatian untuk lebih ditegaskannya PERDA Kota Cirebon No 8 tahun 2015 tentang KTR. Tujuan penelitian ini untuk mengetahui penerapan fungsi manajemen pada kebijakan KTR di Kota Cirebon tahun 2020.

\section{BAHAN DAN METODE}

\section{Kebijakan Publik}

1. Pengertian Kebijakan Publik

Kebijakan publik adalah serangkaian keputusan yang saling berkaitan oleh aktor politik atau kelompok aktor, berkenaan dengan tujuan yang dipilih beserta cara-cara untuk 
mencapainya dalam suatu situasi. Keputusan-keputusan itu pada prinsipnya masih berada dalam batasan kewenagan-kewenangan kekuasaan dari pada faktor tersebut.(Cirebon, n.d.) Kebijakan publik sebagai "is whatever government choose to do or not to do" (apapun yang dipilih pemerintah untuk dilakukan atau untuk tidak dilakukan). Definisi ini menekankan bahwa kebijakan publik adalah mengenai perwujudan "tindakan" dan bukan merupakan pernyataan keinginan pemerintah atau pejabat publik semata. Di samping itu pilihan pemerintah untuk tidak melakukan sesuatu juga merupakan kebijakan publik karena mempunyai pengaruh (dampak yang sama dengan pilihan pemerintah untuk melakukan sesuatu (Abdul Wahab, 2012). Adapun yang menyatakan bahwa kebijakan publik adalah pemanfaatan yang strategis terhadap sumberdaya yang ada untuk memecahkan masalah-masalah publik atau pemerintah. Selanjutnya dikatakan bahwa kebijakan publik merupakan suatu bentuk intervensi yang dilakukan secara terus-menerus oleh pemerintah demi kepentingan kelompok yang kurang beruntung dalam masyarakat agar mereka dapat hidup, dan ikut berpartisipasi dalam pembangunan secara luas (Islamy, 2009).

\section{Proses Kebijakan Publik}

Proses analisis kebijakan publik adalah serangkaian aktivitas intelektual yang dilakukan dalam proses kegiatan yang bersifat politis. Aktivitas politik tersebut nampak dalam serangkaian kegiatan yaitu:

1) Adopsi kebijakan adalah kebijakan yang di tawarkan oleh para perumus kebijakan, pada akhirnya salah satu dari alternative kebijakan tersebut diadopsi dengan dukungan dari mayoritas legislative, consensus antara lembaga atau putusan peradilan.

2) Implementasi kebijakan adalah suatu program kebijakan hanya akan menjadi catatancatatan elit jika program tersebut tidak di implementasikan, yakni dilaksanakan oleh badan-badan administrasi maupun agen-agen pemerintah di tingkat bawah.

3) Evaluasi kebijakan adalah kebijakan yang telah di jalankan akan di nilai atau di evaluasi, untuk melihat sejauh mana kebijakan yang di buat untuk meraih dampak yang di inginkan, yaitu memecahkan masalah yang di hadapi masyarakat (Suharno, 2010).

\section{Manajemen Kebijakan}

1. Pengertian Manajemen Kebijakan

Manajemen adalah pergerakan tenaga manusia, modal dan peralatan lainnya secara terpadu untuk mencapai sasaran atau tujuan tertentu Implementasi adalah (Pujiastuti, 2013). Adapun dalam kamus ilmiah popular manajemen merupakan pengelolaan usaha, 
kepengurusan, ketatalaksanaan penggunaan sumber daya secara efektif untuk mencapai sasaran yang di inginkan (T. Chan Sam M dan Sam Tuti, 2007). Tahap-tahap Manajemen Kebijakan:

1) Perencanaan merupakan salah satu fungsi fundamental dari manajemen yang sangat menentukan, karena di dalamnya termuat apa yang diinginkan oleh suatu organisasi serta langkah-langkah akan perlu dilakukan untuk mencapai tujuan yang telah ditetapkan.

2) Pelaksanaan atau penggerakan yang dilakukan setelah organisasi memiliki perencanaan dan melakukan pengorganisasian dengan memiliki struktur organisasi termasuk tersedianya personil sebagai pelaksana sesuai dengan kebutuhan unit atau satuan kerja yang dibentuk. diantara kegiatan pelaksanaan adalah melakukan pengarahan, bimbingan dan komunikasi termasuk koordinasi.

3) Evaluasi adalah suatu kegiatan yang untuk mengetahui informasi tentang pelaksanaan program dan informasi tersebut digunakan untuk menentukan alternatif yang tepat dalam pengambilan keputusan (Dewi, 2016).

\section{Faktor Penentu Manajemen Kebijakan}

Manajemen kebijakan yang dibuat oleh pemerintah tidak hanya ditujukan dan dilaksanakan untuk intern pemerintah saja, akan tetapi ditujukan dan harus dilaksanakan pula oleh seluruh masyarakat yang berada di lingkungannya. Faktor penentu manajemen kebijakan yaitu:

1) Respek anggota masyarakat pada otoritas dan keputusan pemerintah

Dalam hal ini, faktor penentu keefektifan pelaksanaan kebijakan didasarkan atas penghormatan dan penghargaan publik pada pemerintah yang legitimat. Apabila publik menghormati pemerintah yang berkuasa oleh karena legitimasinya, maka secara otomatis mereka akan turut memenuhi ajakan pemerintah melalui berbagai bentuk kebijakan.

2) Kesadaran untuk menerima kebijakan

Bermain dalam ranah kesadaran publik merupakan hal yang sulit sebab pemerintah perlu merubah mindset warga ada tidaknya sanksi hukum

3) Faktor penentu lainnya agar manajemen kebijakan dapat berjalan efektif adalah sanksi hukum. Orang akan melaksanakan dan menjauhkan suatu kebijakan karena mereka takut terkena sanksi hukum yang dijabarkan oleh kontan suatu kebijakan seperti dinda, kurungan, dan sanksi lainnya. 
4) Kepentingan pribadi atau kelompok

Subjek kebijakan (individu atau kelompok) sering memperoleh keuntungan langsung dari suatu kebijakan. Maka tidak heran apabila efektifitas suatu manajemen kebijakan ikut berpengaruh oleh penerimaan dan dukungan subjek kebijakan atas pelaksanaan suatu kebijakan.

5) Bertentangan dengan nilai yang ada

Manajemen kebijakan pun berjalan tidak efektif apabila bertentangan dengan sistem nilai yang ada pada suatu daerah.

6) Keanggotaan seseorang atau sekelompok orang

Dalam suatu organisasi Kepatuhan atau ketidakpatuhan seseorang atau sekelompok orang pada kebijakan dapat disebabkan oleh bergabung atau tidak bergabungnya subjek kebijakan dalam suatu organisasi tertentu atau tidak.

7) Wujudnya kepatuhan selektif

Tidak dapat dipungkiri bahwa tidak semua subjek kebijakan patuh atas aturan atau kebijakan yang ditetapkan oleh pemerintah. Hal ini terjadi karena sebagian besar masyarakat yang patuh pada suatu kebijakan tertentu, tetapi tidak pada kebijakan lain.

8) Waktu Efektif tidaknya suatu implementasi kebijakan

Sangat dipengaruhi juga oleh faktor waktu, kebijakan yang pada awalnya ditolak dan dianggap controversial bisa menjadi kebijakan yang wajar dan dapat diterima oleh masyarakat.

9) Sosialisasi

Hal berikutnya yang dapat digunakan untuk menilai efektif tidaknya suatu manajemen kebijakan adalah dilaksanakan atau tidaknya sosialisasi. Sosialisasi merupakan salah satu cara untuk mendistribusikan berbagai hal yang akan dilakukan dan ditempuh oleh pemerintah melalui kebijakan yang diformulasikannya. Tanpa sosialisasi yang cukup baik, makan tujuan kebijakan bisa jadi tidak tercapai.

10) Koordinasi antar lembaga atau antar-organisasi

Manajemen kebijakan tidak jarang melibatkan banyak pemangku kebijakan atau stakeholder. Oleh karena itu, koordinasi merupakan hal penting dalam menilai keefektifan suatu implementasi kebijakan (Dewi, 2016).

\section{Kawasan Tanpa Rokok}

1. Pengertian Kawasan Tanpa Rokok

Kawasan Tanpa Rokok (KTR) adalah ruangan atau area yang dinyatakan dilarang untuk kegiatan merokok atau kegiatan memproduksi, menjual, mengiklankan dan atau 
mempromosikan produk tembakau. Pelaksanaan KTR yang menyatakan bahwa tidak di perbolehkan melakukan aktifitas merokok pada wilayah yang sudah di tetapkan sebagai Kawasan Tanpa Rokok termasuk di fasilitas pelayanan kesehatan (Agustino, 2016).

Tujuan dari kawasan tanpa rokok adalah melindungi masyarakat dengan memastikan bahwa tempat-tempat umum bebas asap rokok. Kawasan tanpa rokok harus menjadi norma, terdapat empat alasan kuat untuk mengembangkan KTR, yaitu untuk melindungi anak-anak dan bukan perokok dari risiko terhadap kesehatan, mencegah rasa tidak nyaman, bau dan kotoran dari ruang rokok, untuk mengembangkan opini bahwa tidak merokok adalah perilaku yang lebih normal, dan KTR mengurangi secara bermakna konsumsi rokok dengan menciptakan lingkungan yang mendorong perokok untuk berhenti atau yang terus merokok untuk mengurangi konsumsi rokoknya.

Asap rokok mengandung molekul radikal bebas. Oksidan dalam asap rokok mempunyai jumlah yang cukup untuk memainkan peranan yang besar terjadinya kerusakan saluran napas. Oksidan asap tembakau menghabiskan antioksidan intraseluler dalam sel paru (in vivo) melalui mekanisme yang dikaitkan terhadap tekanan oksidan (Renaldi, 2014). Larangan merokok perlu diterapkan di tempat-tempat umum, tempat kerja dan transportasi umum. Penerapan kawasan tanpa asap rokok tidak saja untuk memenuhi hak bukan perokok untuk menghirup udara bersih dan sehat, namun juga membantu perokok untuk dapat menahan dan menunda kebiasaan merokoknya dan sebagai langkah awal perokok untuk berhenti merokok. Penerapan kawasan tanpa tanpa rokok juga semakin menyadarkan banyak orang akan bahaya adiktif rokok dan mengembalikan norma untuk tidak merokok di tempat umum, terutama diruangan tertutup (Agustino, 2016).

\section{Peraturan Daerah Tentang Kawasan Tanpa Rokok}

Pemerintah Republik Indonesia telah mengatur kebijakan pelarangan merokok melalui KTR yang dijabarkan dalam UU nomor 36 tahun 2009 pasal 162 dan keputusan bersama menteri kesehatan dan menteri dalam negeri nomor 188/Menkes/PB/I/2011 serta PP Nomor 109 tahun 2013 bahwa upaya kesehatan lingkungan ditunjukan untuk mewujudkan kualitas lingkungan yang sehat, baik fisik, kimia, biologi maupun sosial yang memungkinkan setiap orang mencapai derajat kesehatan yang setinggi-tingginya(Ehan, 2015) Penetapan KTR di suatu wilayah pada dasarnya adalah kebijakan untuk memberikan perlindungan terhadap perokok pasif dari dampak buruk asap rokok, serta menyediakan udara bersih dan sehat yang merupakan hak asasi manusia. Menurut (Saifullah et al., 2019) dalam KTR terdapat area yang telah di tetapkan yaitu: 
1) Fasilitas Pelayanan Kesehatan

Suatu tempat atau alat yang digunakan untuk menyelenggarakan upaya pelayanan kesehatan baik secara promotif, preventif, kuratif dan rehabilitative yang dilakukan oleh pemerintah dan masyarakat. Faslitias pelayanan kesehatan yang dimaksud adalah Rumah Sakit, Rumah Bersalin, Poliklinik, Puskesmas, Balai pengobatan, Laboratorium, Posyandu, Tempat praktek kesehatan swasta.

2) Tempat Proses Belajar Mengajar

Sarana yang digunakan untuk kegiatan belajar, mengajar, pendidikan dan pelatihan. Tempat kegiatan proses belajar mengajar yang di maksud adalah sekolah, perguruan tinggi, balai pendidikan dan pelatihan, balai latihan kerja, bimbingan belajar, dan tempat kursus.

3) Tempat Anak Bermain

Area atau tempat baik terbuka maupun tertutup, yang digunakan untuk kegiatan bermain anak-anak. Tempat anak bermain yangdimaksud adalah kelompok bermain, penitipan anak, pendidikan anak usia dini (PAUD), dan taman kanak-kanak.

4) Tempat Ibadah

Bangunan atau ruang tertutup atau terbuka yang memiliki ciri-ciri tertentu yang khusus dipergunakan untuk beribadah bagi para pemeluk masing-masing agama secara permanen, tidak termasuk tempat ibadah keluarga. Tempat ibadah yang dimaksud adalah pura, masjid atau mushola, gereja, vihara, dan klenteng.

5) Angkutan Umum

Alat trasnportasi bagi masyarakat yang berupa kendaraan darat, air, dan udara biasanya dengan kompensasi. Angkutan umum yang dimaksud adalah bus umum, taxi, angkutan kota termasuk kendaraan wisata, bus angkutan anak sekolah dan bus angkutan karyawan, angkutan antar kota, angkutan pedesaan, angkutan air, dan angkutan udara.

6) Tempat Kerja

Ruang atau lapangan terbuka atau tertutup, bergerak atau tetap dimana tenaga bekerja, atau yang dimasuki tenaga kerja untuk keperluan suatu usaha dan dimana terdapat sumber bahaya. Tempat kerja yang dimaksud adalah perkantoran pemerintah baik sipil maupun TNI dan POLRI, perkantoran swasta, industri, dan bengkel.

7) Tempat Umum

Semua tempat terbuka atau tertutup yang dapat diaskses oleh masyarakat umum dan atau tempat yang dapat dimanfaatkan bersamasama untuk kegiatan masyarakat yang 
dikelola oleh pemerintah, swasta, dan masyarakat. Tempat umum yang dimaksud adalah pasar modern, pasar tradisional, tempat wisata, tempat hiburan, hotel, restoran, tempat rekreasi, halte, terminal angkutan umum, terminal angkutan barang, pelabuhan, dan bandara.

8) Tempat Lain yang ditetapkan

Tempat terbuka yang dimanfaatkan bersama-sama untuk kegiatan masyarakat.

\section{Rokok}

1. Pengertian Rokok

Rokok adalah hasil olahan tembakau terbungkus termasuk cerutu atau bentuk lainnya yang dihasilkan oleh tanaman Nicotiana tabacum, Nicotiana rustica dan spesies lainnya atau sintesisnya yang mengandung nikotin dan tar dengan atau tanpa bahan tambahan. Namun kandungan nikotin dalam rokok telah teruji berbahaya dan menimbulkan efek kecanduan (Adiksi) meskipun konsentrasi dalam rokok hanya sekitar 1-1,3 mg. Sudah lama diketahui bahwa nikotin beracun bagi sel-sel saraf. ${ }^{18}$ Asap rokok terdiri atas campuran substansisubstansi kimia dalam bentuk gas dan partikel-partikel terdispersi di dalamnya. Sampai saat ini, telah berhasil diisolasi beragam zat kimia yang jumlahnya mencapai 3000 senyawa dalam daun tembakaunya sendiri dan mencapai lebih dari 4000 senyawa pada asap rokok. Sebagian besar bahan atau senyawa-senyawa tersebut bersifat toksik bagi berbagai macam sel dalam tubuh kita. Substansi toksik dalam bentuk gas, yaitu berupa karbon monoksida (CO), hidrogen sianida ( $\mathrm{HCN})$, dan oksida nitrogen. Sedangkan substansi toksik dalam bentuk zat kimia yang volatil seperti nitrosamin, formaldehid banyak terdapat dalam asap rokok. Zat-zat ini dapat memberikan efek toksiknya dengan mekanisme spesifik dan pada sel-sel atau unit-unit makromolekuler sel tertentu terutama pada sistem pernapasan (Amelia, Nasrul, \& Basyar, 2016).

2. Bahaya Merokok

Merokok suatu kegiatan yang sangat merugikan, tidak hanya bagi sang perokok atau yang sering disebut (perokok aktif) tapi juga bagi orang di sekitar atau yang sering disebut (perokok pasif). Setiap asap rokok yang ditimbulkan dari rokok, terkandung bahan-bahan yang berbahaya bagi kesehatan (Fitria, Triandini, C.Mangimbulude, \& Karwur, 2013). Meskipun saat ini ada rokok modern (elektrik), namun tetap saja memiliki bahaya. Baca: Bahaya Efek Samping Rokok Elektrik. Oleh karena itu, dengan tingginya angka kematian yang disebabkan oleh merokok. beberapa penyakit bahaya akibat merokok di bawah ini menggerogoti kesehatan tubuh terdapat 10 penyakit paling berbahaya akibat merokok antara lain: kanker paru-paru' kanker lain' penyakit paru obstruktif kronik (PPOK)' 
penyakit jantung, stroke' diabetes' asma' infertilitas dan impotens' infeksi saluran pernafasan' dan risiko penyakit bagi orang terdekat (Amelia et al., 2016).

\section{METODE}

Rancangan penelitian ini menggunakan jenis penelitian kualitatif, merupakan proses penyelidikan untuk memahami masalah sosial berdasarkan pada penciptaan gambaran holistic yang dibentuk dengan kata-kata, melaporkan pandangan informan secara terperinci dan disusun dalam sebuah latar alamiah (Arikunto, 2005). Fokus penelitian ini penerapan fungsi manajemen pada kebijakan KTR di Kota Cirebon Tahun 2020.Dalam penelitian ini informan berjumlah 8 orang yang dibagi menjadi informan kunci dan informan pendukung. Informan kunci dalam penelitian ini adalah petugas Dinas kesehatan (R1), petugas satuan polisi pamong praja (R2), petugas puskesmas (R3) dan petugas kelurahan (R4) yang berjumlah 4 orang. Sedangkan informan pendukung merupakan masyarakat (R5) yang ada di Kota Cirebon berjumlah 4 orang. Adapun informan pada penelitian ini meliputi kriteria yaitu: petugas kawasan tanpa rokok, masyarakat, berusia antara 15-40 tahun dan tidak pikun sehingga mampu memberikan informasi data, tidak tuna wicara dan dapat diajak berkomunikasi, bersedia menjadi informan, representative, dan tidak cacat. Teknik pengambilan sampel dalam penelitian purposive sampling (Ulber Silalahi, 2013). Instrumen penelitian ini adalah peneliti sendiri.

Teknik pengumpulan data dalam penelitian ini yaitu wawancara berpedoman pada daftar pertanyaan yang telah disediakan, pengamatan menggunakan tabel observasi untuk mengetahui aktivitas merokok, dan dokumentasi. Teknik analisis data dilakukan pada saat pengumpulan data berlangsung. Pada tahap pertama, peneliti mengumpulkan data yang telah ditentukan sejak awal yang melibatkan aktor, aktifitas dan terjadinya fenomena. Kondensasi data sebagai proses pemilihan, penyederhanaan dan transformasi data mentah yang di dapat dari lapangan. Data yang telah terkumpul dan diklasifikasikan selanjutnya disajikan baik dalam bentuk kalimat atau uraian. Dan tahap akhir penarikan kesimpulan yang dilakukan secara terus-menerus sepanjang proses penelitian berlangsung (Sugiyono, 2015). Teknik validitas data dalam penelitian ini menggunakan metode triangulasi, yang meliputi: triangulasi Sumber, triangulasi data, dan triangulasi metoda (Ulber Silalahi, 2013).

\section{HASIL DAN PEMBAHASAN}

\section{Perencanaan}

Pada perencanaan manajemen kebijakam KTR terdapat sosialisasi rencana penetapan kawasan tanpa rokok, penetapan kawasan tanpa rokok dan sosialisasi pasca peluncuran, petugas 
KTR melakukan sosialisasi KTR, untuk memberikan pengetahuan bahwa sudah di tetapkannya PERDA terkait KTR, tokoh masyarakat dan masyarakat Kota Cirebon masih belum sepenuhnya mengetahui penetapan PERDA tersebut. Petugas KTR mempunyai wewenang atau tugas untuk mengkomunikasikan kebijakan KTR kepada semua pihak. Komunikasi atau sosialisasi dalam manajemen kebijakan terdiri dari 3 dimensi yaitu dimensi transmisi, dimensi kejelasan, dan dimensi konsistensi. Dimensi transmisi mengharapkan agar kebijakan disampaikan kepada sasaran dapat dipahami dan dilaksanakan dengan baik. Sosialisasi menjadi alat komunikasi untuk menyampaikan kebijakan KTR di area KTR. Kegiatan sosialisasi perencanaan penetapan KTR yang dilakukan oleh petugas, berikut hasilnya:

R1 : “...untuk pemberian sosialisasi perencanaan penetapan KTR dengan cara memberikan materi terkait KTR kepada sasaran di berbagai media. Sosialisasi kami sudah lakukan 100\%, sudah berkali-kali memanggil semua dari tingkat kelurahan sampai kecamatan bahkan dari pihak rumah sakit dan seluruh stakeholder terkait KTR. Wajib semua sasaran kebijakan untuk menerapkan aturan tersebut tahun 2015. Untuk tahun ini 2015, kami memang masih dalam tahap sosialisai tapi untuk tempat umum, rumah sakit, tempat kesehatan lainnya, sekolah harus menjalankan larang merokok tersebut wajib."

R2 : “... kalau di Kota Cirebon semua orang hampir tau bahwa sudah ada kebijakan KTR,. kami juga sudah sampaikan gambaran umum terkait kawasan tanpa rokok bersama pemerintah daerah, semua dipanggil dari kecamatan nanti ia sampaikan ke warganya. Pada saat pelaksanaan kami turun ke semua tempat sasaran untuk melakukan penindakan kalau sudah tersusun semua teknisnya."

R3 : “... pernah dilakukan sosialisai tapi untuk yang formal itu sudah lama, sudah 5 tahun ada aturan kawasan tanpa rokok dengan cara lewat sosial media dan langsung ke masyarakat. Kalau untuk sosialisasi yang berlanjut itu disampaikan pada saat pelaksanaan yustisi/razia."

R4 : “... sosialisasi perencanaan kawasan tanpa rokok sudah disampaikan kepada masyarakat dengan secara langsung dan tidak langsung pada saat penetapan KTR. Kalau untuk area KTR Kota Cirebon sudah ada poster yang bertuliskan kawasan tanpa rokok”

Dimensi kejelasan menginginkan kebijakan dapat dimengerti oleh sasaran kebijakan. Kejelasan yang diterima oleh sasaran kebijakan sangat penting agar mengetahui tujuan dan maksud dari kebijakan tersebut. Beberapa masyarakat mengaku tidak tahu akan adanya kebijakan tersebut, berikut penjelasannya: 
R5 : “... kalau untuk dilarang merokok di sembarang saya tahu mba, tapi masih banyak juga tuh yang merokok di sembarang tempat. Saya juga baru tau kalau ada aturannya, kalau kena tegur mungkin pada saat ada razia saja. Jadi selagi tidak razia saya merokok saja.”

R5 : “... memang masih sering ada yang merokok di sembarang tempat apalagi sambil nunggu penumpang sambil duduk di becak. Saya baru tau kalo ada aturannya mba" R5 : “... saya juga tidak tau kalau ada aturannya tersendiri tentang merokok tapi susah juga kalau mau merokok harus berhentiin angkot dulu keluar jauh-jauh.”

Dimensi konsistensi Kota Cirebon belum bisa dianggap sebagai sikap konsisten karena belum terdapat sebuah tempat di lingkungan yang digunakan khusus untuk merokok dan lingkungan tersebut masih digunakan bebas untuk merokok tanpa adanya teguran dari petugas, berikut penjelasannya:

R5 : “... masih banyak yang merokok pada saat berkendara mba apalagi saat ngumpul pinggir jalan hampir semua teman-teman saya merokok di situ seperti tempat untuk khusus merokok tapi karena faktor kebiasaan saja jadi di anggap di situ tempat untuk merokok, memang jarang orang mau di tegur"

R5 : “... memang susah karena kalau tidak ada razia kan kita di tegur dan di sanksi kalau lagi ada razia saja mba jadi kebiasaan merokok dimana aja susah untuk di hilangkan"

\section{Pelaksanaan}

Sumber daya manusia yang digunakan sebagai pelaksana kebijakan kawasan tanpa rokok di kota cirebon adalah dinas kesehatan, puskesmas, kelurahan dan Satpol PP, berikut penjelasannya:

R1 : “... kalau tim khusus untuk menangani masalah kebijakan tentang larangan rokok ini sudah ada, namun untuk pengamanan lingkungan Kota Cirebon ada Satpol PP nanti yang menegur atau melarang tentang masalah rokok, namun masih banyak yang acuh untuk menegur."

Apakah dari pihak Satpol PP sendiri ada tim pelaksana khusus setiap harinya untuk yustisi/razia di sekitar Kota Cirebon?

R2 : “... belum ada kalau untuk tim yang setiap hari melaksanakan yustisi/razia, jadi memang untuk disini saya yang patroli dan ada pos untuk melihat sekeliling lingkungan jadi saya yang di tugaskan untuk melarang orang merokok di sekitar area KTR supaya tidak merokok di area tersebut."

Pemasangan tanda dilarang merokok menggunakan anggaran dari Dinas Kesehatan, berikut penjelasannya: 
R1 : “... untuk anggaran KTR ini menggunakan anggaran media cetak Dinas Kesehatan untuk pemasangan poster terkait larangan merokok."

Sumber daya peralatan yang digunakan untuk melaksanakan kebijakan KTR hanya menggunakan tanda larangan merokok, tidak ada peralatan khusus karena tidak ada program khusus untuk menangani kebijakan tersebut, berikut penjelasannya:

R1: “...kami hanya memasang poster tanda larangan saja untuk tidak merokok selebihnya yang namanya peraturan apalagi undang - undang tau atau tidak harus dilaksanakan. Belum ada tempat khusus untuk merokok di lingkungan umum kalau di Dinas Kesehatan sendiri sudah $a d a ”$.

Meski sudah ada tanda larangan untuk merokok, apakah bapak masih merokok di sembarang tempat?

R5 : “... ya gimana ya mba, disini memang ada tanda larangan merokok, tapi bagaimana juga kita yang merokok tidak ada tempat khusus untuk merokok, terus juga saya merokok sembarangan juga jarang ada yang menegur kalau sedang tidak razia."

Sumber daya kewenangan di Kota Cirebon dalam pelaksanaan kebijakan KTR kurang maksimal. Selain sosialisasi, meski sudah ada program yustisi/razia yang mendukung manajemen kebijakan KTR di Kota Cirebon, berikut penjelasannya:

R2 :"... kalau dari tim khusus untuk KTR ini hanya berupa larangan saja dan program khusus ada yang mengatur, meskipun sudah ada yang mengatur untuk pelaksanaan yustisi/razia masih sering terbaikan dan tokoh masyrakat bahkan petugas KTR masih banyak yang melanggar.

\section{Evaluasi}

Sebuah manajemen kebijakan tentu saja memiliki standar operating procedure (SOP). SOP digunakan sebagai pedoman oleh pelaksana kebijakan dalam melaksanakan tugasnya, berikut penjelasannya:

R1 :“... Memang untuk kebijakan yang di laksanakan sudah sesuai SOP, bentuk pelaksanaan dan evaluasi ini diawasi oleh pihak dinas kesehatan dan Satpol PP dan kami sudah memiliki tim khusus."

Perencanaan merupakan suatu proses menganalisis dan memahami sistem yang di pakai untuk membuat sosialisasi rencana penetapanKTR, peluncuran penetapan KTR dan sosialisasi pasca peluncuran untuk mencapai tujuan yang telah ditetapkan, dalam suatu sistem pengawasan yang terus menerus sehingga dapat dicapai tujuan yang optimal. Dalam manajemen kebijakan, perencanaan terdiri dari 3 dimensi yaitu dimensi transmisi, dimensi kejelasan, dan dimensi 
konsistensi (Setiawan, 2004). Dimensi Transmisi dalam perencanaan kebijakan mengharapkan pelaksana kebijakan memberitahukan tentang kebijakan yang akan dilaksanakan. Penjelasan kebijakan mencakup tujuan yang akan dicapai dan persiapan apa saja yang dilakukan untuk mencapai tujuan kebijakan tersebut. Kota Cirebon melakukan komunikasi kebijakan KTR melalui cara sosialisasi. Sosialisasi dilakukan petugas KTR kita Cirebon yang lama sejak kurang lebih lima tahun yang lalu setelah adanya PERDA tentang KTR. Penyampaian informasi mengenai kebijakan KTR atau dilarang merokok juga dilakukan langsung kepada masyarakat. Komunikasi antara dinas kesehatan, Satpol PP, Kelurahan dan Puskesmas adalah menjelaskan bahwa Kota Cirebon sudah diterapkannya KTR.

Dimensi transisi dalam perencanaan kebijakan KTR dilakukan dengan cara sosialisasi sejak di diberlakukannya aturan. Dimensi Kejelasan merupakan komunikasi yang dilakukan oleh pelaksana kebijakan, yang diharapkan dapat diterima secara jelas oleh sasaran kebijakan. Kejelasan yang diterima oleh sasaran kebijakan sangat penting agar mengetahui tujuan dan maksud. Hasil wawancara dengan petugas KTR dan masyarakat mengenai pelaksanaan kebijakan KTR di Kota Cirebon menunjukkan masih banyak masyarakat mengaku tidak tahu akan adanya kebijakan tersebut. Hasil observasi menemukan beberapa masyarakat yang merokok di area larangan, bahkan ditemukan puntung rokok yang dibuang sembarangan di sekitar lingkungan larangan merokok. Sosialisasi kebijakan KTR di Kota Cirebon masih belum jelas karena ada masyarakat yang mengaku tidak tahu mengenai kebijakan tersebut.

Dimensi konsistensi dalam implementasi kebijakan menjelaskan bahwa dimensi konsistensi menginginkan manajemen kebijakan berlangsung efektif dengan cara pemberian perintah-perintah pelaksanaan harus konsisten dan jelas KTR adalah Dinas Kesehatan Kota Cirebon, Satpol PP, Kelurahan dan Puskesmas. Petugas KTR Kota Cirebon sudah memberikan sanksi bagi masyarakat yang melanggar aturan larangan merokok. Namun, konsistensi dalam pelaksanaan kebijakan di Kota Cirebon belum terlihat karena belum terdapat tempat khusus untuk merokok. Sedangkan dalam PERDA kota Cirebon Nomor 8 tahun 2015 tentang kawasan tanpa rokok menjelaskan bahwa pimpinan atau penanggung jawab kawasan tanpa rokok wajib menyiapkan tempat khusus untuk merokok. Kesimpulan dari penjelasan dimensi konsistensi yaitu sudah melaksanakan larangan untuk tidak merokok di sembarang tempat, namun belum menyiapkan area untuk khusus tempat merokok.

Pelaksanaan menjadi faktor pendukung keberhasilan manajemen kebijakan yang dilakukan oleh pelaksana kebijakan kepada objek kebijakan. Sumber daya pada proses manajemen kebijakan KTR di Kota Cirebon berhubungan dengan kesiapan dari pihak pelaksana. 
Sumber daya tersebut dapat berupa sumber daya manusia, sumber daya anggaran, sumber daya peralatan, dan sumber daya kewenangan (Suharno, 2010).

Sumber daya manusia merupakan salah satu variabel yang mempengaruhi keberhasilan dan kegagalan pelaksana kebijakan. Sumber daya manusia (staff), harus cukup (jumlah) dan cakap (keahlian) (Tangkilisan, 2003). Oleh karena itu, sumber daya manusia harus ada kegiatan dan kelayakan antara jumlah staf yang dibutuhkan dan keahlian yang dimiliki sesuai dengan tugas pekerjaan yang ditanganinya. Saat ini jumlah pelaksana kebijakan di Kota Cirebon kurang dan terkendala antar pelaksana dan adanya tim khusus untuk melaksanakan KTR masih kurang. Kesimpulan Sumber daya manusia dalam manajemen kebijakan kawasan tanpa rokok di Kota Cirebon yaitu Dinas kesehatan dan Satpol PP.

Sumber daya anggaran yang dimaksud adalah dana yang diperlukan untuk membiayai operasionalisasi pelaksana kebijakan. Sumber daya keuangan (anggaran) akan mempengaruhi keberhasilan pelaksanaan kebijakan. Disamping program tidak dapat dilaksanakan dengan optimal, terbatasnya anggaran menyebabkan disposisi para pelaku kebijakan rendah, bahkan akan terjadi goal displacement yang dilakukan oleh pelaksana kebijakan terhadap pencapaian tujuan. Maka dari itu, perlu ditetapkan suatu sistem insentif dalam sistem akuntabilitas. Sumber daya anggaran yang digunakan untuk pelaksanaan kebijakan KTR Kota Cirebon tidak dianggarkan secara khusus oleh pihak dinas kesehatan. Pihak Dinas Kesehatan dan Satpol PP tidak menganggarkan khusus karena tidak ada program khusus untuk menanggapi kebijakan tersebut. Sosialisasi menjadi langkah awal petugas KTR menanggapi kebijakan tersebut namun sosialisasi yang dilakukan tidak membutuhkan anggaran karena hanya menggunakan penempelan poster dan menggunakan media sosial.

Sumber daya peralatan merupakan sarana yang digunakan untuk operasionalisasi manajemen suatu kebijakan yang meliputi gedung, tanah, dan sarana yang semuanya akan memudahkan dalam memberikan pelayanan dalam manajemen kebijakan. Manajemen kebijakan KTR juga membutuhkan peralatan untuk menunjang keberhasilan tujuan kebijakan. PERDA Kota Cirebon No. 8 tahun 2015 tentang KTR memberikan perintah kepada pimpinan atau penanggung jawab KTR untuk memasang tanda KTR dan seharusnya di sediakan tempat khusus untuk merokok di tempat KTR.

Menurut Edward III sumber daya kewenangan menjadi kekuatan oleh suatu lembaga untuk mempengaruhi lembaga tersebut dalam melaksanakan suatu kebijakan. Kewenangan tersebut sangat penting ketika suatu lembaga dihadapkan suatu masalah dan harus segera diselesaikan dengan suatu keputusan (Usman, 2002). Kewenangan dalam pelaksanaan kebijakan KTR di Kota Cirebon adalah Dinas Kesehatan. Kewenangan yang dimiliki oleh Dinas Kesehatan 
belum bisa memaksimalkan pelaksanaan kebijakan KTR. Yustisi/razia dilakukan kurang lebih lima tahun yang lalu. Hasil observasi menemukan sarana pendukung yang dibuat petugas KTR berupa tanda tulisan dilarang merokok diacuhkan oleh beberapa perokok.Pelaksanaan kebijakan KTR di Kota Cirebon sudah memasang tanda kawasan tanpa rokok di lingkungan dan area KTR namun untuk tempat khusus merokok belum ada.

Evaluasi merupakan suatu proses yang teratur dan sistematis dalam membandingkan hasil yang telah dicapai dengan tolak ukur atau kriteria kebijakan yang telah ditetapkan. ${ }^{36}$ Kajian terhadap masalah yang di temukan, evaluasi menentukan keberhasilan manajemen kebijakan KTR yang melibatkan banyak pihak di dalamnya. Kesimpulan sudah memiliki tim khusus untuk KTR, namum dalam pelaksanaanya masih banyak masyarakat yang melanggar. Pembagian tugas yang tidak terlalu rumit dalam pelaksanaan KTR ternyata masih belum bisa dimaksimalkan. Masih banyak pelanggaran yang terjadi di Kota Cirebon tersebut.

\section{KESIMPULAN DAN SARAN}

Proses penyampaian perencanaan penetapan tentang kebijakan KTR di Kota Cirebon belum maksimal karena masih banyak masyarakat yang hanya sekedar mengetahui larangan merokok tetapi tidak mengetahui isi dari kebijakan untuk tidak merokok di KTR. Pelaksanaan KTR mengeluarkan anggaran untuk pemasangan poster larangan merokok, namun anggaran yang mesti di keluarkan untuk membuat tempat khusus untuk merokok itu tidak laksanakan. Sumber daya manusia masih kurang untuk mendukung kebijakan KTR. Dalam pelaksanaan KTR sudah memiliki pedoman atau SOP yang jelas terkait larangan merokok. Meski sudah ada tim khusus untuk menangani, namun pembagian tugas terkait kebijakan KTR tidak diindahkan.

Diharapakan dapat meningkatkan sosialisasi pemberian informasi perencanaan terkait adanya aturan KTR ke masyarakat, pembuatan tempat untuk merokok khususnya di area KTR, sebaiknya dilakukan razia rutin terhadap lingkungan KTR dan ditingkatkan kembali proses pengawasan, pembinaan, komunikasi tentang pentingnya menerapkan kebijakan KTR, baik lintas sektor dan masyarakat.

\section{UCAPAN TERIMA KASIH}

Terima kasih kepada seluruh pihak diantaranya Dinas kesehatan Kota Cirebon, Satuan polisi pamong praja, Puskesmas, Kelurahan, dan masyarakat kota Cirebon, yang telah terlibat dalam pelaksanaan penelitian dengan judul "penerapan fungsi manajemen kebijakan Kawasan Tanpa Rokok (KTR) di Kota Cirebon tahun 2020”, semoga hasil publikasi penelitian pengabdian 
ini dapat bermanfaat baik secara teoritis bagi pengembangan ilmu khususnya dan bermanfaat aplikatif baik bagi pemegang kebijakan dan masyarakat luas.

\section{DAFTAR PUSTAKA}

Abdul Wahab. (2012). Analisis Kebijakan dari Formulas Kebijaksanaan Implementasi Kebijakan Negara. Jakarta: Bumi Aksara.

Agustino, L. (2016). Dasar-dasar kebijakan publik. Edisi Revisi. Bandung: Alfabeta.

Amelia, R., Nasrul, E., \& Basyar, M. (2016). Hubungan Derajat Merokok Berdasarkan Indeks Brinkman dengan Kadar Hemoglobin. Jurnal Kesehatan Andalas, 5(3), 619-624. https://doi.org/10.25077/jka.v5i3.587

Arikunto, S. (2005). Manajemen Penelitian. Jakarta: Rineka Cipta.

Ariska, M. (2017). Implementasi Peraturan Daerah Kabupaten Bintan Nomor 1 Tahun 2016 Tentang Kawasan Tanpa Rokok. Jurnal Ilmu Administrasi Negara (JUAN), 5(1), 45-53.

Badan Penelitian dan Pengembangan Kesehatan Kementrian RI. (2018). Riset kesehatan dasar 2018.

Cirebon, S. P. P. P. dan D. K. K. (n.d.). Data Evaluasi Yustisi KTR.

Dewi, R. K. (2016). Study analisis kebijakan. Bandung: pustaka setia.

Ehan, Z. (2015). Kawasan Tanpa Rokok, Studi Pada Rumah Sakit Umum. E-Jurnal Katalogis, 3 nomer 5, 58-67.

Fitria, Triandini, R., C.Mangimbulude, J., \& Karwur, F. F. (2013). Merokok dan Oksidasi DNA. Sains Medika, 5(2), 121-127. https://doi.org/10.20473/ijph.v11i1.2016.78-88

Huri, D., Hernawan, D., \& Seran, G. G. (2019). Pengaruh Implementasi Kebijakan Peraturan Daerah Nomor 12 Tahun 2009 Tentang Kawasan Tanpa Rokok Oleh Satuan Polisi Pamong Praja Terhadap Penegakan Disiplin Masyarakat Di Kawasan Umum Kota Bogor. Jurnal Governansi, 5(1), 1. https://doi.org/10.30997/jgs.v5i1.1698

Islamy, M. I. (2009). Prinsip-prinsip perumusan kebijakan Negara. Jakarta: Sinar Grafika.

Maharrani, E., Isniati, I., \& Kasni Astiena, A. (2015). Studi Implementasi Kebijakan Larangan Merokok Di Universitas Andalas Tahun 2012. Jurnal Kesehatan Masyarakat Andalas, 9(1), 3. https://doi.org/10.24893/jkma.9.1.3-9.2014

Pujiastuti, B. M. dan N. T. (2013). Teori - teori politik dewasa ini Jakarata. Jakarta: PT Raja Grafindo Persada.

Renaldi, R. (2014). Implementasi Kebijakan Kawasan Tanpa Rokok (KTR) pada Mahasiswa di Lingkungan Sekolah Tinggi Ilmu Kesehatan Hang Tuah Pekanbaru. Jurnal Kesehatan Komunitas, 2(5), 233-238. https://doi.org/10.25311/jkk.vol2.iss5.82 
18 | Penerapan Fungsi Manajemen Pada Kebijakan Kawasan Tanpa Rokok Di.

Saifullah, Ikbal, M., \& Thamrin, H. (2019). Implementasi Kebijakan Peraturan Daerah Nomor 18 Tahun 2016 Tentang Kawasan Tanpa Rokok Di Rumah Sakit Arifin Nu'mang Kabupaten Sidenreng Rappang. Jurnal Moderat, 5(1), 44-55.

Setiawan, G. (2004). Implementasi dalam Birokrasi Pembangunan. Jakarta: Balai pustaka.

Sugiyono. (2015). Metode penelitian manajemen. Alfabeta.

Suharno. (2010). Dasar-dasar kebijakan publik. Yogyakarta: UNY Press.

T. Chan Sam M dan Sam Tuti. (2007). Analisis kebijakan pendidikan di era otonomi daerah. Jakarta: Rajagrafindo Persada.

Tangkilisan, H. N. S. (2003). Implementasi Kebijakan Publik. Transformasi Pikiran George Edward. Jakarta.

Ulber Silalahi. (2013). Metode Penelitian Sosial. Bandung: PT. Refika Aditama.

Usman, N. (2002). Konteks Implementasi Berbasis Kurikulum. Jakarta.

Wali Kota Cirebon. (2015). Peraturan Daerah Kota Cirebon No 8 tentang Kawasan Tanpa Rokok. 